ISBN 978-93-84468-83-5

International Conference on Issues in Business, Economics, Marketing and Mathematics

(IBEMM-16)

Singapore Dec. 5-6, 2016

\title{
The Importance of Spirituality Dimensions in the Entrepreneurial Development for College Graduates
}

\author{
Hani Sirine $^{1}$, Elisabeth Penti Kurniawati ${ }^{2}$ and Lieli Suharti ${ }^{3}$ \\ ${ }^{1,2,3}$ Satya Wacana Christian University, Indonesia
}

\begin{abstract}
Human being as spiritual being needs to be nurtured spiritually so that they can be optimal in their work and their calling. Actualization of this calling can be made through entrepreneurship. The purpose of this study is to determine the importance of spiritual dimensions (vision, faith/hope, love altruistic, meaning/calling, membership) in the development of entrepreneurship (entrepreneurship intention, entrepreneurial networking, entrepreneurial capability, and entrepreneurial success). The analysis technique of this study uses multiple linear regressions with a sample of 67 graduates of Satya Wacana Christian University who have had and run their own business. The results show that the spirituality dimensions (vision, faith/hope, altruistic love, meaning/calling, membership) significantly influence entrepreneurial intention, entrepreneurial networking, entrepreneurial capability, and entrepreneurial success. When it is tested partially, the significant positive effect on entrepreneurial intention is vision and faith/hope. Faith/hope also has significant positive effects on entrepreneurial networking. Vision, faith/hope, and meaning/calling has significant positive effects on entrepreneurial capabilities. Lastly, faith/hope, and meaning/calling has significant positive effects on entrepreneurial success.
\end{abstract}

Keywords: spirituality, spiritual leadership, workplace spirituality, entrepreneurial development

\section{Introduction}

Since the 1980s focus has shifted from contingency behavioral leadership theory, by studying the behavior of leaders who shall fit the particular situation, leading towards strategic leadership that emphasizes vision, motivation, and control through values or culture in the organization adaptive to changes in the organizational environment. As expressed by Fry (2003) about the need for change in the leadership model, he states that spiritual leadership is a set of values, attitudes, and behaviors necessary to motivate ourselves and others intrinsically, so that each one has a feeling of spiritual survival through membership and calling.

For an entrepreneur, it is important to have spiritual leadership in the entrepreneurial process, of which it is not only related to problem-solving activities in a management position, but also related to human mental, confidence, time efficiency, creativity, fortitude, perseverance, sincerity and morality in running independent businesses. The dominance of entrepreneurial studies usually ignore spirituality altogether or these factors only have a small stimulus (Cromie \& Hayes, 1991; Gartner, et al., 1992; Krueger, 2000). The integration of spirituality into entrepreneurial exploration will provide a deeper and congruent understanding when people incorporate their mind, body, and soul into the dynamics of employment and business growth.

Cogliser and Brigham (2004) stated that skills in entrepreneurial leadership improve employers' ability to overcome the challenges associated with creation of new business, growth and success, and to adapt to the competitive business environment. It is important for an entrepreneur to seek, evaluate and develop opportunities by tackling a number of forces that hinder the creation of something new. 
One way to tackle unemployment in Indonesia is by developing a productive entrepreneurship. For this purpose, it needs efforts to improve the quality of human resources by building competencies (skills, knowledge, and attitude) in order that they will have a competitive advantage for expansion of employment opportunities through independent entrepreneurship.

According to Milliman et al. (2003), the study of spirituality in the context of workplace and leadership is still in its infancy. In fact, some studies show that more and more individuals are spiritually-based; more benefits are realized by those individuals in terms of satisfaction, commitment, productivity, flexibility and creativity. The same thing is expressed by Kauanui et al. (2009) which stated that only a few studies of entrepreneurship that studied on factors related to spirituality as a body of literature of entrepreneurship that could be used as the main motivating factor to pursue entrepreneurial lifestyle. Based on the reason above, this study will assess the importance of spirituality dimension of the entrepreneurial development on graduates, who have had and run their own businesses. Whereas, the issues in this study is: how does influence of the spirituality dimension on the entrepreneurship development? The benefits of this research are for entrepreneurs to evaluate and improve their entrepreneurship, and for universities to facilitate their graduates in entrepreneurship development.

\section{Literature Review}

\subsection{Spirituality}

Cavanagh (1999) defines spirituality as the spirit to find meaning and the purpose of life so as to have a real life. The same opinion made by Javanmard (2012) which states that spirituality as a force to motivate life, an energy that inspires an individual to reach his final destination or the purpose of self that is transcendent. Rust and Gabriels (2011) supported the statement of Mitroff and Denton (1999), which stated that spirituality is one's inner experience through connection with other people and with higher power and the whole nature to find meaning and purpose of life. The definition of spirituality highlights two constructions, namely spiritual leadership and spirituality in the workplace.

\subsection{Spiritual Leadership}

Spiritual leaders must have a vision and when they move towards this vision, (Yagboubi et al., 2010). Fry (2003) defines the spiritual leadership consists of values, attitudes, and behaviors necessary to motivate leaders themselves and others so that they have spiritual life through calling or membership.

According to MacArthur (1998), people who have hope or belief that their vision will be realized, they will be able to face the challenges and sufferings as long as they achieve their goals. Altruistic love is defined as a sense of wholeness, harmony, and well-being generated for treatment, care and respect for themselves and other people (Fry, 2003). According to Aydin and Ceylan (2009), the altruistic love inspires us to love all people without exception. This love makes people prefer to suffer for others and stop to be selfish.

\subsection{Spirituality in Workplace}

Ashmos and Duchon (2000) state that the spirituality in the workplace is the recognition of inner life that is maintained through meaningful work that occurs in the society. Therefore, the definition of spirituality in the workplace has 3 (three) dimensions: life inner, meaningful work, and community, where inner life of someone is connected with the inner lives of others (Maynard, 1992; Miller, 1992), that by Fry et al. (2005) is called as membership.

Spirituality considers a meaningful job as a work that is not only interesting or challenging, but also looks for deeper meaning of life greater goals, aspirations and needs for someone of a meaning job, and how he makes a contribution to others (Fox, 1995; Neal, 1997; Ashmos and Duchon, 2000).

\subsection{Entrepreneurship Development}

According Agbim (2013), entrepreneurship is the process of realizing innovative intentions by an individual or groups of individuals, either new or old companies through a network to acquire the necessary capabilities 
that will enhance the success of businesses in facing of environmental uncertainty. Entrepreneurial intention is the first step in the formation of new businesses (Lee and Wong, 2004). Economic motivation and individual independence are the main driving forces that create the entrepreneurial intention (Hunjra et al., 2011). According Johannisson (2000), those who have the entrepreneurial intention and entrepreneurial capability can gain access to information and finance sources that are useful through a network of entrepreneurship.

Golden and Powell (2000) explains that entrepreneurial capability is the flexibility source for changes. Ravichandram and Lertwangsatien (2005) further confirm that the flexibility can facilitate individuals and companies to quickly and efficiently in using of technology as the art to continue maintaining the existing businesses. Proper utilization of opportunities can lead to the success of entrepreneurship, so that it can influence other people life and bring innovative products or services.

\subsection{Model and Research Hypothesis}

This study examines the importance of the spiritual dimensions in entrepreneurship development. Vision, hope/faith, altruistic love, meaning/calling, and membership are identified as dimensions of spirituality. Meanwhile, the intention of entrepreneurship, entrepreneurial networking, entrepreneurial capability and entrepreneurial success are identified as the development of entrepreneurship. The model in this study is as follows:

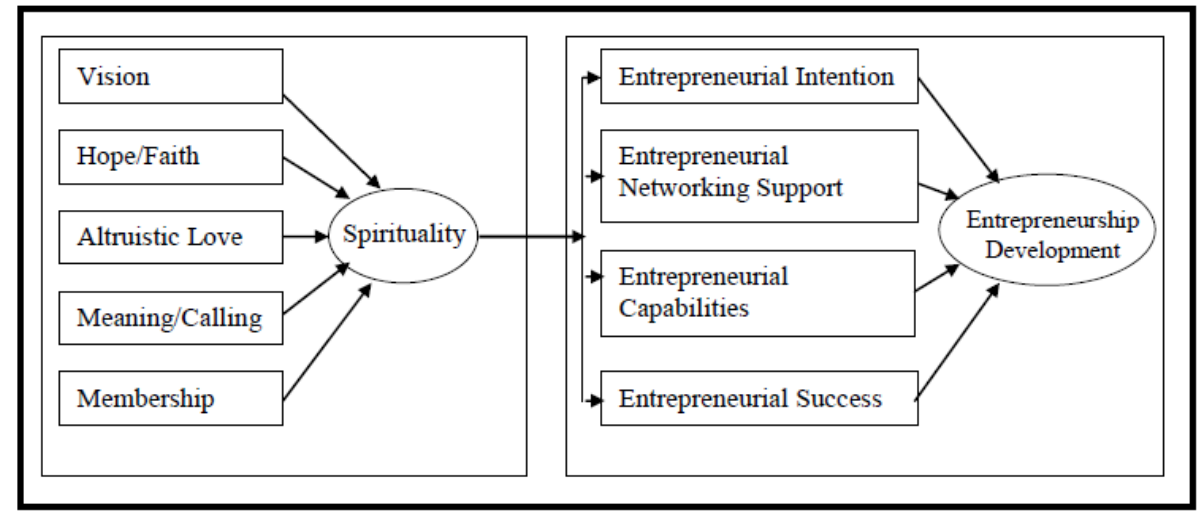

Fig. 1: Research Model

From the research model above, hypotheses that are proposed in this study:

H1: Spirituality dimensions significantly influence entrepreneurial intention.

$\mathrm{H} 2$ : Spirituality dimensions significantly influence entrepreneurial networking.

H3: Spirituality dimensions significantly influence entrepreneurial capability.

H4: Spirituality dimensions significantly influence entrepreneurial success.

\section{Research Methods}

This study uses a method of survey by using purposive sampling with criteria of graduates of Satya Wacana Christian University, Indonesia, who have owned and run their own business. 67 graduates are specified as respondents. Data collection is done by distributing questionnaires to graduates. To test the hypotheses, the technique of multiple linear regressions is used with help from SPSS.

\section{Results and Discussion}

In this study $54 \%$ of 67 respondents are predominantly male and $70 \%$ of respondents are $21-30$ years old. $52 \%$ of respondents participate in the practice of entrepreneurship, obtained from seminars or workshops of entrepreneurship. Meanwhile, $46 \%$ respondents are involved in trade. Among 67 respondents that are surveyed, most of them have income per month $\leq 10$ million (58\%) rupiahs and profit per month of $\leq 5$ million (58\%) rupiahs with the age of businesses $\leq 5$ years $(64 \%)$. 
Results of validity test by using of an approach of corrected item-total correlations shows that all items used in this study are valid, as indicated by the value of $r$ of each item of which it is similar and greater than the critical $r, 0.30$. Thus, all items of empirical indicators can be used in further data processing. Results of reliability test are based on the value of Cronbach's Alpha $(\alpha)$ show that nine variables that are studied meet the elements of reliability with value of Alpha Cronbach $(\alpha)$ is greater than 0.60 (Malhotra, 2010).

To find out the average answer of respondents on each studied variable, we can see them in following table:

TABLE I: Statistical Description

\begin{tabular}{lrrrr}
\hline \multicolumn{1}{c}{ Variable } & Average & Standard Deviation & Minimum & Maximum \\
\hline Spirituality Dimension - Vision & 4.22 & .546 & 3 & 5 \\
Spirituality Dimension -Hope/Faith & 4.28 & .598 & 3 & 5 \\
Spirituality Dimension -Altruistic Love & 3.99 & .707 & 2 & 5 \\
Spirituality Dimension - Meaning/Calling & 4.33 & .613 & 3 & 5 \\
Spirituality Dimension -Membership & 3.97 & .651 & 2 & 5 \\
Entrepreneurial Intention & 4.52 & .587 & 3 & 5 \\
Entrepreneurial Networking & 4.34 & .592 & 3 & 5 \\
Entrepreneurial Capabilities & 4.16 & .567 & 3 & 5 \\
Entrepreneurial Success & 4.25 & .659 & 2 & 5 \\
\hline \hline
\end{tabular}

\subsection{Influence of Spirituality Dimensions on Entrepreneurship Intention}

The results of regression test of spiritual dimensions toward the entrepreneurial intention are shown in the following table. Vision and hope/faith significantly influence entrepreneurial intention at alpha 5\%. Thus, it shows that vision and the hope/faith have inspired the graduates to develop ideas that will direct their attention and act along these direction to achieve their hopes on jobs that they earn.

TABLE II: Regression Test of the Influence of Spirituality Dimensions toward Entrepreneurial Intention

\begin{tabular}{cccccc}
\hline \hline Model & Coefficients & t-value & Significance & F Sig & ${\text { Adjusted } \mathbf{R}^{2}}^{\mathbf{2}}$ \\
\hline (Constant) & .967 & 1.764 & .083 & .000 & .381 \\
Vision & .342 & 2.618 & .011 & & \\
Hope/Faith & .225 & 1.980 & .052 & & \\
Altruistic Love & -.113 & -1.072 & .288 & & \\
Meaning/ Calling & .183 & 1.620 & .110 & & \\
Membership & .203 & 1.641 & .106 & & \\
\hline \hline
\end{tabular}

For altruistic love, meaning/calling, there is no significant effect on entrepreneurial intention. However, membership significantly influences entrepreneurial intention at alpha 10\%. Meanwhile, simultaneously the spirituality dimensions significantly influence entrepreneurial intention for they have a significance level of 0,000 (below of alpha 0.05). Variation of influence of spiritual dimensions towards the entrepreneurial intention is $38.1 \%$. This means that there is still $61.9 \%$ variation of entrepreneurial intention obtained from other variables outside the model.

\subsection{Influence of Spirituality Dimensions on Enterprise Networking}

The effect of the spiritual dimensions toward entrepreneurial networking are shown in following table, that show that only the hope/faith that has a significant influence on the entrepreneurial networking at alpha 5\%. This means that hope/faith will motivate graduates to get connected to the provider of entrepreneurial networking so that they will have a good relationship with their business networks and feel contribution from their business networks, such as access to information and resources needed by their businesses.

TABLE III: Regression Test of the Influence of Spirituality Dimensions toward Entrepreneurial Networking

\begin{tabular}{cccccc}
\hline \hline Model & Coefficients & t-value & Significance & F Sig & Adjusted R \\
\hline (Constant) & 1.913 & 3.000 & .004 & .004 & .177 \\
Vision & .212 & 1.398 & .167 & & \\
Hope/Faith & .279 & 2.111 & .039 & & \\
Altruistic Love & -.132 & -1.078 & .285 & & \\
Meaning/Calling & -.005 & -.042 & .967 & & \\
Membership & .224 & 1.558 & .124 & & \\
\hline \hline
\end{tabular}

Meanwhile, variables of vision, altruistic love, meaning/calling, and membership do not influence the entrepreneurial networking. However, simultaneously the dimensions of spirituality significantly influence 
towards network of entrepreneurship. This is shown by the test of $\mathrm{F}$ regression in which it shows a significance level of 0.004 (below 0.05). For variation of the dimensions of spirituality toward entrepreneurial networking is $17.7 \%$. Thus, $82.3 \%$ of variation of entrepreneurial networking obtained from other variables outside the model.

\subsection{Influence of Spirituality Dimensions on the Entrepreneurship Capabilities}

The influence of spiritual dimensions toward the entrepreneurial capability can be seen in following table which show that hope/faith significantly influence entrepreneurial capability at alpha 5\%, while vision and meaning/calling significantly influence on the capability of entrepreneurship at alpha $10 \%$. This means that vision, hope/faith, and meaning/calling encourage graduates to have skills in interpersonal relation, writing, communication, technology, networking, training, working in team, and a skill to monitor the environment within their organizations.

TABLE IV: Regression Test of the Influence of Spirituality Dimensions toward Entrepreneurial Capabilities

\begin{tabular}{cccccc}
\hline \hline Model & Coefficients & t-value & Significance & F Sig & Adjusted R $^{\mathbf{2}}$ \\
\hline (Constant) & 1.924 & 3.189 & .002 & .002 & .197 \\
Vision & .248 & 1.731 & .089 & & \\
Hope/Faith & .320 & 2.558 & .013 & & \\
Altruistic Love & -.166 & -1.428 & .158 & & \\
Meaning/Calling & .237 & 1.903 & .062 & & \\
Membership & -.137 & -1.004 & .320 & & \\
\hline \hline
\end{tabular}

For variable altruistic love and membership, there is no influence on entrepreneurial capability because its significance level at above 5\%. In simultaneous tests, spiritual dimensions significantly influence the entrepreneurial capability because they have level of significance below 0.05 (0.002). The variation of the influence of spiritual dimensions of the entrepreneurial capability is $19.7 \%$. This means that $80.3 \%$ variation of entrepreneurial capability comes from the variables outside the model.

\subsection{Influence of Spirituality Dimensions on the Entrepreneurial Success}

The influence of spirituality dimensions toward the entrepreneurial success are shown in the following table, which shows that hope/faith significantly influences the entrepreneurial success at alpha 5\%. Meanwhile, meaning/calling significantly influences the entrepreneurial success at $10 \%$ alpha. It means that hope/faith and meaning/calling encourages graduates to dedicate themselves for the lives of others positively, and successfully make innovation in the products and services management in their organizations.

TABLE V: Regression Test of the Influence of Spirituality Dimensions toward Entrepreneurial Success

\begin{tabular}{cccccc}
\hline \hline Model & Coefficients & t-value & Significance & F Sig & Adjusted R \\
\hline (Constant) & .564 & .880 & .382 & .000 & .331 \\
Vision & .087 & .572 & .569 & & \\
Hope/Faith & .442 & 3.330 & .001 & & \\
Altruistic Love & -.005 & -.041 & .967 & \\
Meaning/Calling & .236 & 1.789 & .079 & \\
Membership & .107 & .743 & .461 & \\
\hline \hline
\end{tabular}

Whereas, vision, altruistic love, and membership do not significantly influence entrepreneurial success because they have significance level at above 0.05. Spirituality dimensions simultaneously and significantly influence the entrepreneurial success. It can be seen through the $F$ test of regression in which its significance level at 0.000 (below 0.05). The above results also suggest that variation of entrepreneurial success can be demonstrated through spirituality dimensions which amounted to $33.1 \%$. Thus, $66.9 \%$ variation of entrepreneurial success is obtained from other variables outside of this research model.

\section{Discussion about the Findings}

The results of this study show that vision has a significant influence on the intention of entrepreneurship and entrepreneurial capability. Thus, vision will inspire graduates to give attention to their work so that they will have the capacity to grow continuously in terms of technology, organization and operation, as well as innovation. 
The results of this study also indicate that hope/faith has a significant positive effect on entrepreneurial intention, entrepreneurial networking, entrepreneurial capability, and entrepreneurial success. Hope/faith encourages graduates to act according to the track in achieving their hopes on their job. In addition, hope/faith inspires graduates to be persons who have inner control or discipline in risk-taking, innovation, orientation of changes, persistence, imagination, direction, flexibility, competitiveness power, optimism, and courage, so that they can use them with a passion to help others.

In this study, the meaning/calling has a significant positive effect on the entrepreneurship skill and entrepreneurial success. Meaning/calling will encourage graduates to have skills necessary to obtain competitive advantage through value creation based on the founded opportunities and strategies. Meaning/calling also inspires graduates to give a greater appreciation to employees, customers, and communities.

\section{Conclusion and Suggestion}

The results of this study show that the spirituality dimensions (vision, hope/faith, altruistic love; meaning/calling and membership) significantly influence the entrepreneurial intention, entrepreneurial networking, entrepreneurial capability, and entrepreneurial success. When they are tested partially, the dimensions that significantly give a positive effect on entrepreneurial intention are vision and the hope/faith. Hope/faith also gives a significant positive effect on entrepreneurial networking. Meanwhile, vision, hope/faith, and meaning/calling can have significant positive influences on the entrepreneurial capability. Lastly, hope/faith and meaning/calling give influence positively and significantly on the entrepreneurial success.

Introduction of spirituality in entrepreneurship development program for students is relatively important. This can be achieved by teaching students to connect with God through hope/faith of which then connected to the fellow human beings through interpersonal relationship. Students can also choose the meaning/calling that in line with their interests and talents, so that they can design a future for themselves through the work they select. This will make students to have a passion of practicing their calling. Besides, learning of the needed skills is important according to their entrepreneurial selection necessary based on vision, hope/faith, and faith/calling, and then this will get rid of all forms of fear, worry, anger, jealousy, and guilt. All destructive emotions will turn into forms of understanding and appreciation to others and it will demonstrate an unwavering commitment towards the practice of their selected works.

\section{References}

[1] Agbim, K.C. (2013). The Relative Contribution of Management Skills to Entrepreneurial Success: A Survey of Small and Medium Enterprises (SMEs) In the Trade Sector. International Organization of Scientific Research Journal of Business and Management, 7(1), 08-16.

[2] Ashmos, D. and Duchon, D. (2000). Spirituality at Work: A Conceptualization and Measure. Journal of Management Inquiry, 9(2), 134-145.

https://doi.org/10.1177/105649260092008

[3] Aydin, B. and Ceylan, A. (2009). The Effect of Spiritual Leadership on Organizational Learning Capacity. African Journal of Business Management, 3(5), 184-190.

[4] Burts, R.S. (1992). Structural Holes. Cambridge, MA: Harvard University Press.

[5] Cavanagh, G.F. (1999). Spirituality for Managers: Context and Critique. Journal of Organizational Change Management, 12(3), 186-199.

https://doi.org/10.1108/09534819910273793

[6] Cogliser, C. and Brigham, K.H. (2004). The Intersection of Leadership and Entrepreneurship: Mutual Lesson To Be Learned . Leadership Quarterly, 15, 771-799.

https://doi.org/10.1016/j.leaqua.2004.09.004 
[7] Cromie, S. \& Hayes, J. (1991). Business Ownership as a Means of Overcoming Job Dissatisfaction. Personnel Review, 20(1), 19-24. https://doi.org/10.1108/00483489110006853

[8] Fox, M. (1995). The Reinvention of Work: A New Vision of Livelihood for Our Time. San Francisco, CA: Harper.

[9] Fry, L.W. (2003). Toward A Theory of Spiritual Leadership. The Leadership Quarterly, 14, 693-727. https://doi.org/10.1016/j.leaqua.2003.09.001

[10] Fry, L.W. (2005). Introduction to The Leadership Quarterly Special Issue: Toward A Paradigm of Spiritual Leadership. The Leadership Quarterly, 16, 619-622.

https://doi.org/10.1016/j.leaqua.2005.07.001

[11] Fry, L.W., Vitucci, S. and Cadillo, M. (2005). Spiritual Leadership and Army Transformation: Theory, Measurement and Establishing A Baseline. Leadership Quarterly, 16(1), 835-862.

https://doi.org/10.1016/j.leaqua.2005.07.012

[12] Gartner, W.B., Bird, B.J. \& Starr, J.A. (1992). Acting As If: Differentiating Entrepreneurial From Organizational Behavior. Entrepreneurship: Theory and Practice, pp. 13-31.

[13] Golden, W. and Powell, P. (2000). Towards A Definition of Flexibility: In Search of Holy Grail. Omega International Journal of Management Science, 28(4), 373-384.

https://doi.org/10.1016/S0305-0483(99)00057-2

[14] Hellman, T. and Puri, M. (2002). Venture Capital and the Professionalism of Start-Up Firms. Journal of Finance, 57, 169-197.

https://doi.org/10.1111/1540-6261.00419

[15] Hunjra, A.I., Ahmad, H.M., Ur-Rehman, K. and Safman, N. (2011). Factors Influencing Intention to Create New Venture among Young Graduates. African Journal of Business Management, 5(1), 121-127.

[16] Javanmard, H. (2012). The Impact of Spirituality on Work Performance. Indian Journal of Science and Technology, 5(1), 1961-1966.

[17] Johannisson, B. (2000). Networking and Entrepreneurial Growth. In D. Sexton and H. Landstrom (Eds.), the Blackwell Handbook of Entrepreneurship. Oxford: Blackwell.

[18] Kauanui, S.K., Thomas, K.D., Sherman, C.L., Waters, G.R. and Gilea, M. (2009). Entrepreneurship and Spirituality: An Exploration Using Grounded Theory. Fort Myers, FL: Florida Gulf Coast University.

[19] Krueger, N.F. (2000). The Cognitive Infrastructure of Opportunity Emergence. Entrepreneurship Theory and Practice, 24(3), 5-23.

[20] Lee, S.H. and Wong, P.K. (2004). An Exploratory Study of Technopreneurial Intentions: A Career Anchor Perspective. Journal of Business Venturing, 19(1), 7-28.

https://doi.org/10.1016/S0883-9026(02)00112-X

[21] MacArthur, J.F. (1998). In The Footsteps of Faith. Wheaton, IL: Crossway Books.

[22] Malhotra, N. K. 2010. Marketing Research: An Applied Orientation (6th Ed.).United States of America: Pearson Education, Inc. https://doi.org/10.1108/S1548-6435(2010)6

[23] Maynard, H.B. (1992). Evolution of Human Consciousness. In J. Renesch (Ed.), New Traditions In Business: Spirit and Leadership in The 21st Century (Pp. 39-52). San Francisco, CA: Berrett-Koehler.

[24] Miller, W.C. (1992). How Do We Put Our Spiritual Values To Work? In J. Renesch (Ed.), New Tradition in Business: Spirit and Leadership in The 21st Century (Pp. 69-80), San Francisco, CA: Berrett-Koehler. 
[25] Milliman, J., Czaplewski, A.J. and Ferguson, J. (2003). Workplace Spirituality and Employee Work Attitudes: An Exploratory Empirical Assessment. Journal of Organizational Change Management, 16(4), 426-447. https://doi.org/10.1108/09534810310484172

[26] Mitroff, I.A. and Denton, E.A. (1999). A Spiritual Audit of Corporate America: A Handbook of Spirituality, Religion and Values in the Workplace. San Francisco, CA: Jossey-Bass.

[27] Neal, J.A. (1997). Spirituality in Management Education: A Guide to Resource. Journal of Management Education, 21(1), 121. https://doi.org/10.1177/105256299702100111

[28] Ravichandram, T. and Lertwangsatien, C. (2005). Effect of Information System Resources and Capabilities on Firm Performance: A Resource-Based Perspective. Journal of Management Information System, 21(4), 237-276.

[29] Rust, A.A.E. and Gabriels, C.E.C. (2011). Spirituality in the Workplace: Awareness of the Human Resource Function. African Journal of Business Management, 5(4), 1353-1364.

[30] Tian, J., Wang, K., Chen, Y. and Johansson, B. (2009). From IT Development Capabilities to Competitive Advantage: An Exploratory Study in China. Journal of Business Venturing, 19, 395-415.

[31] Yagboubi, N.M., Moloudi, J. and Banihashemi, S.A. (2010). The Relationship between Spirituality Leadership and Empowerment. American Journal of Scientific Research, 12(2010), 180-186. 